NBER WORKING PAPER SERIES

\title{
GRANDMOTHERS AND GRANDDAUGHTERS: \\ OLD AGE PENSION AND INTRA-HOUSEHOLD \\ ALLOCATION IN SOUTH AFRICA
}

\author{
Esther Duflo \\ Working Paper 8061 \\ http://www.nber.org/papers/w8061 \\ NATIONAL BUREAU OF ECONOMIC RESEARCH \\ 1050 Massachusetts Avenue \\ Cambridge, MA 02138 \\ December 2000
}

Financial support from the Foundation Thiers and the Alfred P. Sloan Foundation is gratefully acknowledged. I thank Josh Angrist, Abhijit Banerjee, Tim Besley, Anne Case, Pierre-Andre Chiappori, Angus Deaton, Andrew Foster, Robert Jensen, Michael Kremer, Emmanuel Saez, and Duncan Thomas for useful comments. The views expressed herein are those of the authors and not necessarily those of the National Bureau of Economic Research.

(C) 2000 by Esther Duflo. All rights reserved. Short sections of text, not to exceed two paragraphs, may be quoted without explicit permission provided that full credit, including $\odot$ notice, is given to the source. 
Grandmothers and Granddaughters: Old Age Pension and

Intra-household Allocation in South Africa

Esther Duflo

NBER Working Paper No. 8061

December 2000

JEL No. H55, O15, I12, D13

\begin{abstract}
$\underline{\text { ABSTRACT }}$
This paper studies whether the impact of a cash transfer on child nutritional status is affected by the gender of its recipient. In the early 1990's, the benefits and coverage of the South African social pension program were expanded for the black population. In 1993, the benefits were about twice the median income per capita in rural areas. Over a quarter of black South African children under age five live with a pension recipient. My estimates suggest that pensions received by women had a large impact on the anthropometric status of girls (it improved their weight given height by 1.19 standard deviations, and their height given age by 1.16 standard deviations), but little effect on that of boys. In contrast, I found no similar effect for pensions received by men. This suggests that the household does not function as a unitary entity, and that they efficiency of public transfer programs may depend on the gender of the recipient.
\end{abstract}

Esther Duflo

Department of Economics

MIT, E52-252G

50 Memorial Drive

Cambridge, MA 02142

and NBER

eduflo@mit.edu 


\section{Introduction}

The idea that an improvement in women's position relative to men's is desirable, not only on equity, but also on efficiency grounds, is often advanced as an argument in favor of policies targeted towards women. A possible channel for these efficiency effects is investment in child health. There is evidence that inadequate nutrition in childhood affects long term physical development (Barker (1990)), as well as the development of cognitive skills. ${ }^{1}$ This in turn affects productivity later in life (Dasgupta (1993), Strauss and Thomas (1998), and Schultz (1999)). Low levels of investment in child health therefore have far-reaching consequences on economic growth, distribution, and welfare. The evidence suggests that, compared to income or assets in the hands of men, income or assets in the hands of women are associated with larger improvements in child health (Thomas (1990)), and larger expenditure shares on household nutrients, health and housing (Thomas (1994)). This observation has been a motivation for the literature on collective household models (Chiappori, $(1988,1992)$, Browning and Chiappori (1998)) which treat the household as a Pareto-efficient unit, whose members have distinct utility functions.

This paper investigates under what condition income data can be used to test the unitary model of the household against a more general model, and therefore to evaluate whether redistributing resources from men to women would increase investments in children. It argues that a test of the unitary model based on income data requires a permanent exogenous change in income that happens after household formation. It then studies an example of such a change, the expansion of the South African Old Age Pension program- a universal, non-contributory, age-tested and means-tested scheme (one of the few successful cash transfer programs in the developing world). Historically, the Old Age Pension was racially discriminatory. At the end of the Apartheid era, the government committed to achieving parity of benefits and eligibility requirements for Whites and Blacks. This was achieved mostly by increasing the benefits received by the Africans. ${ }^{2}$ The new system is universal and non-contributory. All women above 60 and men above 65 are entitled to benefits, subject to a means test. More than one member of the same household can receive the pension simultaneously. In 1993, 80\% of African women over 60

\footnotetext{
${ }^{1}$ Balazs, Jordan, Lewis and Patel (1986) review the biomedical and empirical literature on the relationship between early childhood nutrition and the development of intelligence. Miguel and Kremer (1999) show that school attendance is higher among children treated against worms.

${ }^{2}$ In what follows, I use in general the official denominations of racial groups in South Africa (Africans, White, Colored, and Indians). I sometimes use "Blacks" instead of "Africans" to refer to black South Africans.
} 
and $77 \%$ of African men over 65 received the pension. In most cases they received the maximum amount of 370 rands per months, which was roughly equivalent to twice the median per capita income in rural areas. Living arrangements in South Africa are such that grandparents often live in extended households, with their children and grandchildren. ${ }^{3}$ Over a quarter of African children under the age of five live with a pension recipient.

This paper investigates the effect of men's and women's pensions on child nutrition as it is reflected in child anthropometric indicators, weight for height and height for age. The identification of these effects is complicated by the fact that children living with a pension recipient come, on average, from relatively disadvantaged backgrounds. Case and Deaton (1998) have shown that the program was effective in transferring money predominantly to poor households and, in particular, to households where poor children live. The expansion of the pension program started at the end of 1991, and in 1993 it had been fully operating in all areas for less than a year. Child height is a stock, which reflects accumulated decisions since the birth of the child. Not surprisingly then, in 1993, children living with a pension recipient were on average smaller for their age than other children.

This paper addresses this identification problem in two steps. First, I compare a flow measure of nutritional status, weight for height, of children living in households where there is no eligible member, households where there is an eligible man, and households where there is an eligible woman, after controlling for the presence of a man or a woman who is old, but not old enough to be eligible (e.g. a woman aged between 55 and 60). The results suggest that the presence of an eligible woman increased the weight for height of girls by 1.19 standard deviation, but did not significantly increase that of boys. Pensions received by men are not associated with an improvement in the nutritional status of either girls or boys.

This comparison would be misleading if there are intrinsic differences between households where a member is between 55 and 60 and households where a member is over 60 , or if the expansion of the pension has led to endogenous changes in the composition of the household. Thus, in a second step, I make use of the fact that height for age reflects past as well as current investments. The larger the proportion of her life during which a child was well nourished, the taller she will be, given her age. If the pension had an effect, children born after the expansion of the program have spent a larger fraction of their lives well-nourished if they live with a pension recipient. Thus, I compare the differences in height between young children

\footnotetext{
${ }^{3}$ This is due, in particular, to Apartheid rules, which prohibited the families of migrant workers, those working in the mines or as domestic servants, to join them.
} 
and older children across households, according to whether there is an age-qualified woman, an age-qualified man, or no eligible member living in the household. The results obtained using this second strategy are strikingly similar to those obtained for weight for height: Pensions received by women are associated with an increase of 1.16 standard deviation in the height for age of girls, and no significant effect on that of boys. Pensions received by men are not associated with an improvement in the height for age of either boys or girls.

The identifying assumption is that any difference between children in households where an eligible woman, an eligible man, or no eligible person lives would have been the same in all age groups in the absence of the program. I examine possible threats to the validity of this assumption, and try to address them using additional evidence. In particular, I address the concern of endogenous household formation as a result of the pension by using the information of whether the child has an old grandparent alive (but not necessarily living in the household) as an alternative instrument for the receipt of the pension. I also discuss whether unobserved programs disproportionately affecting children living with eligible persons could explain the patterns I find in the data.

Finally, the propensity to consume out of women's pension income could be larger because it is expected to be received for a longer time, and thus represents a larger permanent income shock. However, I show that the propensity to save out of men's pension income seems to be lower than the propensity to save out of women's pension income, which does not support this alternative interpretation of the data.

The remainder of this paper is organized as follows. In the next section, I discuss the identification conditions of a test of income pooling. Section 3 presents the South Africa pension program and the descriptive statistics. Section 4 discusses the weight for height evidence. Section 5 discusses the height for age evidence. Section 6 discusses the evidence on savings. Section 7 concludes.

\section{Testing the Unitary Model of the Household}

This section argues that a permanent shock to the non-labor income of a household member that was not expected at the time of household formation can be used to test the unitary model of the household. 


\subsection{Model}

Following Chiappori (1988), consider a household consisting of $H$ members indexed by $h$. Each household member receives in every period an exogeneous (for this period) non-labor income $y_{t}^{h}$, and has access to a vector of goods $\left(q_{1}, \ldots . ., q_{N}\right)$ at price $p_{t}$. Leisure is included in the vector of goods. Denote by $q_{t}^{h}$ the consumption of household member $h$ and date $\mathrm{t}$, by $q_{t}$ the vector $\left(q_{t}^{1}, \ldots q_{t}^{H}\right)$, and by $q$ the vector $\left(q_{1}, \ldots . q_{T}\right)$. For simplicity, assume that neither the household as a whole nor any single member have access to saving of borrowing from one period to the next.

Each household member's expected utility depends on his own and the other member's consumption bundle at each date, as well as on an individual specific shock $\epsilon_{t}^{h}$, with mean $\epsilon^{h}$.

$$
V^{h}(q)=E \sum_{t=1}^{T} \delta^{t} u^{h}\left(q_{t}, \epsilon_{t}^{h}\right)
$$

The Pareto efficient allocation is characterized by maximizing $\sum_{h=1}^{H} \theta^{h} V^{h}(q)$ such that $\sum_{h=1}^{H} q_{t}^{h} p_{t}=\sum_{h=1}^{H} y_{t}^{h}=y_{t}$ for $t=1, \ldots, T$.

The unitary household is a special case of the Pareto efficient household. It corresponds either to the "dictatorial case", where one member makes decisions based uniquely on his utility function, or the "unanimity" case, where all household members have the same utility function $u\left(q_{t}, \epsilon_{t}\right)$. The problem then simplifies to maximizing the joint utility function (or the utility function of the dictator) subject to the budget constraint.

\subsection{Test}

Suppose that one of the household members experiences a permanent exogenous shock in nonlabor income (for example, because she becomes eligible for a larger old age pension than previously expected). In the unitary model, this would affect household consumption patterns only through the increase in household non-labor income. As pointed out in the literature, in the collective model, this may also affect them through a modification of this household member's weight in the optimization problem of the household (because it increases its outside option, and hence its reservation utility). One could therefore test the unitary model of the household by testing whether the identity (the gender, for example) of the recipient of a permanent shock in non-labor income affects its use.

Transfer program reform can be a source for such changes. For example, Lundberg, Pollak and Wales (1996) study the effects of a change in the mode of allocation of child benefits in the UK, from a tax credit to a direct payment to the mother. This transfer "from the wallet to the purse" seems to have been associated with an increase in the consumption of women's 
and children's clothing relative to men's clothing in households with children. In this paper, I study whether the expansion of the old age pension program for Black households in South Africa, a permanent modification in the permanent income of eligible household members, led to a different impact on child nutrition, according to the gender of the eligible member.

Similar tests have been proposed in the literature. However, I argue in the next sub-section that tests of "income pooling", which compare the effects of men's and women's income on household allocations, are usually not sufficient to reject the unitary model of the household.

\subsection{Other Tests Based on Income Pooling}

a) Comparison of the Correlation of Women's and Men's Income with Household Consumption Pattern.

Most papers in the literature (e.g. Bourguignon, Browning, Chiappori and Lechene (1994)) compare coefficients of women's and men's total income on household expenditures. In this model, this would be inappropriate, since labor supply is jointly determined with the consumption of all other goods. For example, women would be less likely to work in families which place a huge value on child health. This would cause a negative correlation between women's income and child health, even though the household is unitary.

b) Comparison of the Correlation of Women's and Men's Assets Income with Household Consumption Pattern

The argument developed in section (a) was made by Thomas (1990), who compares instead the effect of non-labor income, notably asset income, received by men and women on child health. However, even in the unitary model, assets held by different members could be correlated in different ways with expenditure or household outcomes depending on who owns the assets.

First, nominal ownership of assets could be correlated with household choices even if it does not directly affect them. For example, more traditional families could be less likely to allow women to retain nominal ownership of assets and also have less healthy children (Berhman, Pollak and Taubman (1995)).

Second, if we abstract from this problem by considering only variations in asset income that are due to differences in household members' assets at the time the household was formed, we need to take into account how the household was formed (Foster (1998)). Suppose first that, once the match is made, the household becomes dictatorial and one member (say, the husband) makes all decisions. For a man, the expected utility from a match depends only on the resources of his future wife. The utility of a woman, however, depends on the resources of the man and the 
choices he is expected to make. Given a man's asset level, a woman therefore always prefers to be matched with someone who has preferences more aligned to hers. Therefore, controlling for the total assets level, the higher the woman's asset level, the better the husband's choice will reflect her preferences. Suppose, instead, that all household members have the same utility function. The predictions of this model depend on the assumptions about the utility function. Suppose for example, that different men can be more or less good at child rearing, and that women are all equally good. If the man's child rearing quality and purchased inputs are complementary, there will be assortative matching- richer women will be matched with husbands that are better at rearing children. Controlling for total assets, a woman's asset level will therefore be correlated with child health.

\section{c) Short Term Variations in Non-labor Income}

To address these concerns, one should look at the effect of unexpected changes in income. However, the final consumption vector of the household in each period depends only on the total non-labor income of the household, and the weight given to each household member, which, at the optimum, should not change with temporary fluctuation in income (this is a re-statement of the result obtained in the mutual insurance literature). It should therefore not depend on transitory variation in the share of non-labor income earned by each household member (Chiappori (1999)). ${ }^{4}$ Therefore, a rejection of pooling of short term fluctuations in non-labor income would be a rejection of Pareto efficiency, not only of the unitary model.

In summary, a convincing test of the unitary model of the household based on comparing the coefficient of different members' income requires a permanent change in non-labor income that happens after household formation, which is the case of the South African pension program. The next section describes the program, and sections 4 and 5 discuss alternative strategies to identify its effects.

\section{Description of the Program}

\subsection{The South African Old Age Pension Program}

This section presents a brief history and an overview of the functioning of the South African Old Age Pension program. It draws extensively from Van der Berg (1994), Lund (1993), and Case and Deaton (1998).

\footnotetext{
${ }^{4}$ Chiappori (1999) considers specifically the case with endogenous labor supply and shows that any sharing rule must satisfy, among other conditions, non-labor income pooling, but not necessarily labor income pooling.
} 
Social pensions were first introduced in the 1920's for Whites. They were intended mainly as a social safety net for a minority of White workers who were not covered by occupational pensions. The pensions were gradually extended, but with very dissimilar benefit levels, to other race groups. During the Apartheid era, the system was racially discriminatory in many respects. First, different means tests were applied to each race group. In 1984, for example, benefits were withdrawn for incomes larger than R 700 per annum (R 500 in Kwa Zulu) for Blacks, and for incomes larger than R 2250 per annum for Whites. Second, the benefit levels were different. In the early 1980's, benefits for Whites were 10 times higher than those for Blacks. ${ }^{5}$ Third, the delivery systems were different. Whites' pensions were distributed through the postal offices, while Africans' were distributed through mobile pay points that did not reach very far out into rural areas. Finally, officials often intentionally underestimated the age of the person, took people off of the computer lists, or otherwise limited the access of legally eligible Africans in order to save on the cost of pensions (Lund (1993)).

Pressures for equity in the treatment of racial groups became strong towards the end of Apartheid. In 1989, the government committed to achieving racial parity in pension treatment (Van der Berg (1994)). The extension of the social pensions to the whole population took several years and they were operating fully in all areas only by the beginning of 1993 . The benefits for Africans improved gradually in the 1980's (from 1555 1990-rands per year in 1980 to 2096 1990-rands per year in 1990), while those for Whites declined rapidly), and then much faster in the 1990's. Benefits where increased to 2444 1990-rands in 1991, to 2677 in 1992 and to 3081 in 1993 (370 1993-rands monthly). The mean monthly household income per capita of Africans in the sample was then 149 rands. Given the high level of unemployment, the pension recipient is frequently the main income earner in the household.

In 1992, the means test was modified and unified across races. The current system is universal and non-contributory. Payments are made to women older than 60 and to men older than 65, subject to a means test. A couple's resources are roughly divided by two when calculating the means test, and the income of other members of the household is not taken into account. There are, therefore, no direct incentives to partition the household or for other household members to stop working. In practice, the means test does not seem to be applied very finely. It is mainly effective in excluding most Whites and those Africans who already have a private pension.

In 1993, in our sample, $60 \%$ of men and $77 \%$ of women eligible on the basis of their age

\footnotetext{
${ }^{5}$ Note that non-pension incomes of Africans were also much smaller, therefore as a fraction of income, the difference was much smaller (Van der Berg (1994)).
} 
were receiving a pension (table 1). Of those, most received the maximum amount. There is no good estimate of the coverage earlier on for two reasons. First, social pensions were administered by several different administrations, which made any evaluation difficult. Second, surveys (including the 1991 census) excluded the "independent homelands", where many Africans live. The coverage increased substantially in the 1990's, due to a new attitude within the administration, a modification of the means test, the computerization of the system, and substantial improvements in the delivery system. ${ }^{6}$

\subsection{Data and Descriptive Statistics}

The data comes from the national survey of South Africa carried out jointly by the World Bank and the South African Labor and Development Research Unit at the University of Cape Town. During the last five months of 1993, 9,000 randomly selected households from all races and areas were interviewed. As part of the survey, measurements of the height and weight of all children aged less than seven years were taken. Environmental factors are especially important determinants of child height in early childhood, thus the World Health Organization recommends limiting the analysis of height and weight measurements to children zero to five years of age (WHO (1986)). In addition, there appears to have been difficulties in the measurement of the oldest children. ${ }^{7}$ I, therefore, follow prior studies (Case and Deaton (1998), Le Roux (1995)), and restrict the sample to children aged 6 to 60 months. For each age in months, I construct height for age Z-scores by subtracting the median and dividing by the standard error in this age and sex group in the NCHS reference population (a group of well-nourished American children). Weight for height Z-scores are constructed in a similar way. ${ }^{8}$

Descriptive statistics of the sample of Black children are presented in table 2. Columns (1), (2), and (3) show the means of the variables used in the analysis by pension status, and columns (4), (5), and (6) show the means by age-eligibility status. Since getting the pension, conditional on being eligible, is an endogenous variable (influenced by current and past decisions of the eligible member and other household members), I focus on the comparison by eligibility status.

\footnotetext{
${ }^{6}$ For example, in the province of Kwa Zulu Natal, the pension is distributed once or twice a month through mobile pay points equipped with ATMs with a fingerprint recognition system (Case and Deaton (1998)).

${ }^{7}$ Some six and seven year old children were recorded by the interviewers to be eight, and thus were not measured. It seems very likely that if the child was tall the surveyor would have assumed the child was older, and therefore the surveyor would have mistakenly excluded that child.

${ }^{8}$ Note that this normalization does not affect the analysis, which relies on the comparison of height between eligible households and those of the same age from non-eligible households and control for the child's age.
} 
The characteristics of households where there is a woman or a man eligible are similar, but households where there is an eligible member are poorer (even after including pension income). They are, not surprisingly, often characterized by the presence of a grandparent, and the absence of the child's father $(64 \%)$, or mother $(18 \%)$. They are also more likely to live in a rural area.

Descriptive statistics of height for age and weight for height are presented in panel C. Children are smaller, controlling for their age, in households where there is a pension recipient. This is not surprising, since even if child nutrition has improved as a result of the extension of the coverage and benefits of the Old Age Pension program, height given age still reflects past deprivations or illnesses, especially among the older children. In contrast, average weight given height, a measure of short run nutritional status, is larger in households where a woman is eligible than in households where a man is eligible and in those where no one is eligible. This suggests that the woman's pension caused an improvement in the child's health.

Table 3 presents mean height for age broken down by eligibility status, by age, and by the gender of the child. Girls born before January 1992 are shorter in households with an eligible woman than in households with no eligible member. Households with an eligible man lie in between. Among children born after January 1992 (after the expansion), the pattern is reversed: Girls are taller if they live with an eligible woman than if they live with no eligible member, and girls living with an eligible man are in between. Both older and younger boys are smaller when they live with an eligible person (woman or man). ${ }^{9}$

The two sets of evidence therefore suggest a similar picture: The pension improved the nutritional status of children (girls, in particular) if it was received by a woman, but not by a man. The following two sections elaborate on this evidence.

\section{Effect of the Pension on Weight for Height}

\subsection{Empirical Specification}

Weight for height of children reflects short run nutrition and illnesses and recovers quickly after periods of malnutrition when proper nutrition is resumed (Ashworth (1969), Martorell and Habicht (1986)).

The household demand for nutrition is in turn determined by the problem we described in section 2. The reduced form demands for the fraction of nutrients relative to the optimal amount

\footnotetext{
${ }^{9}$ Note that the average height for age Z-score is higher for all young children than for older children. This is the standard pattern in developing country data.
} 
for child $i$ in household $j$ in period $t$ can be written as:

$$
N_{i j t}=f\left(\epsilon_{j t}, \theta_{j t}, y_{j t}, u_{i j t}\right)
$$

where $\theta_{j t}$ is the vector of weights in household $j, \epsilon_{j t}$ is the vector of individual preference shocks, $y_{j t}$ is the household's total non-labor income in period $t$, and $u_{i j t}$ is a child specific error term. The reform affected $y_{j t}$ and $\theta_{j t}$ in eligible households.

This expression makes clear that comparing the 1993 weight for height of children who live with an eligible woman, and eligible man, or no eligible member, would confound the effect of eligibility with differences in background, reflected in $\epsilon_{j t}$. In an attempt to control for these differences, I estimate the effect of having an eligible man or an eligible woman in the household, after controlling for the presence of a man or a woman above 50, a man or a woman above 55, and a man above 60 (in 1992), as well as a series of household specific control variables, described below. ${ }^{10}$.As reflected in table 1 , some individuals who are not yet age-eligible receive the pension, but the probability of receiving the pension does increase discretely at age 60 for women and 65 for men. Note that the weight given to the preferences of a person above 55 may reflect the fact that she will earn a pension when she turns 60 (even with a household credit constraint, as in our model). To the extent that this is true, the difference between the coefficient of a man's and woman's pension in this specification is an underestimate of the bargaining power effect.

The regression estimated is therefore:

$$
w_{i j k}=\pi_{f} E_{f}+\pi_{m} E_{m}+\sum_{j=1}^{4} \gamma_{l} \mathbf{1}_{(l=k)}+W_{i j k} \lambda+X_{i j k} \delta+\omega_{i j k},
$$

where $w_{i j k}$ is the weight for height Z-score of a child born in cohort $k$ in family $f, E_{f}$ is equal to 1 if there is an eligible woman in the household and 0 otherwise, $E_{m}$ is equal to 1 if there is an eligible man in the household and 0 otherwise, and $\mathbf{1}_{(l=k)}$ is a dummy indicating the year of birth of the child. $W_{i j k}$ is a vector of variables indicating whether there is a woman or a man above 51 in the household, a man above 51, a woman above 56, a man above 56, and a man above $61 . X_{i j k}$ is a vector of family background variables: mother's and father's educational levels, rural, urban, or metropolitan residence, mother's and father's age, family size, and the number of household members in the following age categories: 0-5, 6-14, 15-24, 25-49. ${ }^{11}$

The identification assumption underlying this exercise is that $E\left[\omega_{i j k} \mid X_{i j k}, W_{i j k}, E_{f}=n, E_{m}=\right.$ $o]=E\left[\omega_{i j k} \mid X_{i j k}, W_{i j k}, E_{f}=n^{\prime}, E_{m}=o^{\prime}\right]$ for any $n, o, n^{\prime}$ and $o^{\prime} . \omega_{i j k}$ reflects both the difference

\footnotetext{
${ }^{10}$ This srtategy was implemented by Case and Deaton (1998) and Bertrand, Miller and Mullainathan (1999)

${ }^{11}$ I have replaced these variables by sample means in cases where the father or the mother of the child were absent.
} 
in nutrition in household $j$, and genetic differences between children. The assumption is that there is no systematic difference in nutrition between eligible and non-eligible households who have an elderly member at home. This assumption may be problematic, as I will discuss below and I will present the results of an alternative specification that relaxes it.

\subsection{Results}

The results from estimating equation 2 are presented in table 4. Panel A presents the results for boys, and panel B presents the results for girls. In columns (1) to (3), I do not distinguish by gender of the eligible member. For girls, the coefficient is positive, but insignificant without controlling for the presence of non-eligible members above 50 (column (1)). When these controls are introduced (column (2)), the coefficient more than doubles (0.35), and becomes significant. It is not affected by introducing additional control variables (column (3)). The direct effect of having household members over 56 is negative and similar across genders. The similarity between the coefficients in column (2) and column (3) is reassuring. It suggests that the dummies for the presence of elderly members capture the effect of observed (and, hopefully, unobserved) family variables. For boys, there seems to be no effect of having an eligible member, irrespective of whether we control for the presence of other elderly members in the household.

Columns (4) to (6) estimate the effects separately according to the gender of the recipient. For girls, column (6) suggests that the effect of having a woman eligible is an increase in weight for height by 0.6 standard deviations (with a standard error of 0.19 ). In contrast, the effect of having a man eligible is an increase in weight for height by an insignificant 0.056 standard deviations. These two numbers are statistically different from each other. For boys, we can now detect a smaller (0.28 standard deviations) and insignificant positive effect of woman's pension on weight for height, and a negative (and insignificant) effect of man's pension. Again, the coefficients are very similar in columns (5) and (6).

Column (7) checks that the difference between the coefficient of a man's and a woman's pension income is not simply due to the fact that, conditional on being eligible on the basis of age, men are claiming the pension much less often than women (perhaps because they are more likely to have worked and have a private pension). To do this, I estimate the following relationship using two-state least squares:

$$
w_{i h k}=\alpha_{f} P E N S_{f}+\alpha_{m} P E N S_{m}+\sum_{j=1}^{4} \gamma_{j} 1_{(j=k)}+W_{i h k} \lambda+X_{i h k} \delta+\omega_{i h k},
$$

$P E N S_{f}$ and $P E N S_{m}$ are dummies indicating respectively whether a woman in the household 
receives a pension and a man in the household receives a pension. The instruments are dummies for the presence of an eligible woman and for the presence of an eligible man. The first stage, presented in the two columns of table A, is, not surprisingly, strong. The coefficient of the "eligible man" dummy in the regression that predicts male pension is 0.39 (with a T statistic of 8) and the coefficient of the "eligible woman" dummy in the regression that predicts female pension is 0.55 (with a $\mathrm{T}$ statistic above 9). ${ }^{12}$ The results in column (6) confirm that the differences between the effect of male and female pension found in columns (4) and (5) was not an artifact of the smaller first stage for male pension. For girls, the effect of woman's pension suggested by these estimates is that it increases weight for height by 1.19 standard deviations. The effect of man's pension is small, negative and insignificant. For boys, the coefficient of woman's pension is positive but only one half as large as the effects on girls (0.58), and insignificant (the standard error is 0.53). The coefficient of man's pension is negative, (-.69) and is insignificant.

In table 5, I examine whether the gender of the parent whose own parent is eligible has an effect as well. Strikingly, only the eligibility of the mother's mother has a significant effect on girl's weight for height.

In summary, the results in these tables provide some suggestive evidence that the old age pension had very different effects on child health if it was received by a woman or a man. Further, there seems to be an all-female link, since the pension seems to be effective only if it was received by the mother of a girl's mother. This evidence points in the direction of rejecting the unitary model of the household. However, in light of the discussion in section 2 , there are caveats to this interpretation, which I now discuss.

\subsection{Caveats}

The essential difficulty is whether controlling for the presence of members above 50, 56, and 61 adequately controls for the differences between eligible and non-eligible households. A first problem could be differences between households where there is a member above 55 and households where there is a member above 60 (different $\epsilon^{t}$, in terms of our model). For example, conditional on being a three generation household, the presence of an elderly grandparent may actually be the sign of a relatively healthy household: The grandmother is old, which indicates that either she, the mother, or both, did not have children very early. ${ }^{13}$ In addition, she is old but still alive, which could indicate that household members are, in general, healthy. Both effects would

\footnotetext{
${ }^{12}$ These coefficients reflect the difference between the probability of receiving the pension when eligible, and when close to eligibility.

${ }^{13}$ It could also indicate that she had many children, but I am directly controlling for this.
} 
bias upwards our estimate of the effect of the pension on weight for height.

A second problem could be that the pension program led to changes in the composition of the household. As we saw in section 2, endogenous household composition could create a positive correlation between unobserved characteristics of the household and the presence of an eligible member. A difference between the coefficient of a woman's and a man's pension could then be obtained even with the absence of any causal effect of the additional income on nutrition.

Some of these problems, which plague any cross-sectional comparison of households by eligibility status, could be addressed by comparing health status in household with or without eligible members, before and after the expansion of the program. There were no representative surveys of Black households before the end of Apartheid. However, we can take advantage of the fact that height is a stock, which reflects accumulated investment in child health and nutrition since birth.

\section{$5 \quad$ Effect of the Pension on Height for Age}

\subsection{Empirical Specification}

In practice, in developing countries, human growth deficits are caused by two preventable factors, inadequate food, and infections. Genetic factors matter for child height, but they become more critical in adolescence. Height given age of young children depends on accumulated investments over the life of the child (Martorell and Habicht (1986)).

I capture this by writing height for age of child $i$ at age $a$ as a function of nutrition since birth: $h_{i}(a)=\phi\left(N_{0 i}, . ., N_{a i}\right)$, where $h_{i}(a)$ is the height for age Z-score attained by child $i$ at age $a, N_{s i}$ (for $s=0$ to $a$ ) is the ratio of the nutrition and other necessary inputs (primary health care, etc.) received by the child relative to what would be optimal at each age. The function $\phi($.$) is weakly increasing in all its arguments and \phi(1,1, . ., 1)=0$. Some properties of the function $\phi($.$) are documented in the medical literature. First, nutrition at a very early age (in the womb$ and in infancy) has long lasting consequences on child height, and in fact, on adult health as well (Barker (1990), Scrimshaw (1997)). Second, the possibility of catch-up skeletal growth after an episode of low growth in infancy is limited. ${ }^{14}$ Most stunting and catch up occurs between 6 months and 24 months of age. Stunting after 24 months of age generally reflects the interaction

\footnotetext{
${ }^{14}$ For example, a study of Jamaican children (Ashworth (1969)) shows that children's weight for height recovers quickly from episodes of acute malnutrition, but that once normal weight for height is achieved, the body stops accumulating nutrients that would allow it to achieve faster skeletal growth.
} 
of nutrition and infection at prior ages (Martorell and Habicht (1986)).

The household demand for nutrition at each age is in turn determined by equation 1 . Combining this equation with the function $\phi($.$) , it is clear that if households eligible for pensions$ have worse characteristics $\epsilon_{j t}$, older children will be smaller in eligible families. However, if the expansion of the pension led to better nutrition, children who are measured when they are younger have been well nourished for a larger fraction of their lives. Therefore, the younger the children are, the smaller their relative disadvantage should be in eligible families. If the pension led to a substantial improvement in nutrition, as we saw in section 4, the youngest children should be taller in eligible households.

The basic idea of the identification strategy is thus to compare the differences between the height of children in eligible and in non-eligible households and between children exposed to the program for a fraction of their lives and children exposed all their lives. Figure 1 gives a graphical illustration of the patterns discussed in section 3. I run a non-parametric regression of height for age on age in months for children living with an eligible woman, with an eligible man, or with no eligible members (children who live with both an eligible man and an eligible woman are included in both regressions). The curves have the traditional pattern for height for age in developing countries Martorell and Habicht (1986). Height for age declines steeply in the first two years of life and then stabilizes. The relative position of the curves is of interest. Older children are smaller when they live with an eligible woman, than when there is no eligible member in their households. The relative advantage of non-eligible children improved for children born between June and December 1990 (non-eligible children seem to be taller for their age at that age). Starting in January 1991 (when the expansion of the program started), the difference becomes smaller, and children born by the end of 1991 are taller if they live with an eligible woman. This catch up is not apparent for older children who live with an eligible grandfather ${ }^{15}$, despite the fact that the height for age of older children who live with an eligible grandfather is very similar to that of children who live with an eligible grandmother.

This discussion suggests the following formulation for comparing the effects of woman's and man's eligibility on height for age.

$$
\begin{aligned}
h_{i j k}= & \pi_{f}\left(Y O U N G * E_{f}\right)+\pi_{m}\left(Y O U N G * E_{m}\right)+\beta_{f} E_{f}+\beta_{m} E_{m}+ \\
& \sum_{l=1}^{4} \gamma_{j} 1_{(l=k)}+X_{i j k} \delta+\sum_{l=1}^{4} 1_{(l=k)} * X_{i j k} \lambda_{j}+\epsilon_{i k k},
\end{aligned}
$$

\footnotetext{
${ }^{15}$ The catch up at the extreme right of the figure is due to one outlier.
} 
where $h_{i f k}$ is the height for age Z-score of a child born in cohort $k$ in family $f$, and the notation is otherwise as before. Children born in January 1992 or later, after the full expansion, $(k=1)$ form the most exposed group $(Y O U N G)$. ${ }^{16}$ The last two terms $\left(X_{i j k}\right.$ and $\left.\sum_{j=1}^{4} 1_{(l=k)} * X_{i l k}\right)$ are family background variables (those discussed in the previous section, plus a control variable for the presence of a household member above 50) and family background variables interacted with cohort dummies. Equation 4 is estimated by OLS, and standard errors are adjusted to take into account the correlation of errors terms between children in the same families as well as heteroscedasticity.

Note that, because even older children were exposed to the program for a fraction of their lives, the differences in differences estimates are a downward biased estimate of the effect of the eligibility (and of the difference between men and women), unless nutrition at a very early age is the only significant determinant of height by age 5 .

\subsection{Results}

Results of estimating equation 4 are presented in table 6. Column (1) estimates the effect of eligibility without control variables, and Column (2) introduces control variables. For girls, living with an eligible member is associated with an increase of 0.68 standard deviations in height for age, with control variables. The main effect of eligibility is negative, but substantially smaller than the interaction (-.17), and not significant after we introduce the control variables. This is comforting, since it reduces the likelihood that eligible and non- eligible households are subject to different shocks (different programs, for example). For boys, the effect of eligibility is small (0.11) and not significant. The main effect of eligibility is similar to that on girls' height $(-0.15)$.

Columns (3) and (4) estimate separately the effect by gender of the recipient. For girls, having a woman eligible in the household increases the height for age of young children relative to older children by 0.71 standard deviations (with a standard error of 0.34 ). The effects of man's eligibility status is small and negative. For boys, the coefficient of the interaction between woman's eligibility and a dummy for being young is only 0.18 (not significant), and that of the interaction between woman eligibility and a dummy for being young is negative and insignificant.

\footnotetext{
${ }^{16}$ Table A2, in the appendix, shows that the results are robust to the exclusion of children born in 1991 (during the expansion). The table also presents specifications that include children born in the treated group. As expected, since it was only the beginning of the expansion, the magnitude of the effect decline, and the effect looses significance. The comparison boys-girls and women-men remains unaffected.
} 
As in the weight for height specification, I estimate in table 6 the effect of the pension implied by these coefficients. I estimate the following equation using two-stage least squares.

$$
\begin{aligned}
h_{i f k}= & \alpha_{f}\left(Y O U N G * P E N S_{f}\right)+\alpha_{m}\left(Y O U N G * P E N S_{m}\right)+\beta_{f} E_{f}+\beta_{m} E_{m}+ \\
& \sum_{j=1}^{4} \gamma_{j} 1_{(j=k)}+X_{i f k} \delta+\sum_{j=1}^{4} 1_{(k=j)} * X_{i f k} \lambda_{j}+\epsilon_{i f k},
\end{aligned}
$$

where $P E N S_{f}$ and $P E N S_{m}$ are dummy variables respectively equal to 1 if a woman (a man) receives a pension. The interactions $Y O U N G * P E N S_{f}$ and $Y O U N G * P E N S_{m}$ are endogenous, and they are instrumented using the interactions $\left(Y O U N G * E_{f}\right)$ and $\left(Y O U N G * E_{m}\right)$ as instruments.

The results, in columns (1) and (3) of table 7, suggest that a pension received by a woman led to an increase of at least 1.16 standard deviations in the height of girls, and to a much smaller effect on the height of boys (0.28 standard deviations, not significant). Pensions received by males seem to have no effect on the height of either boys or girls. These results are strikingly similar to the results we obtained with weight for height.

In table 8 , I consider separately the effect of eligibility of the mother's mother, the father's father, the father's mother and the mother's father. In this case as well, the effect of the mother's mother pension on the nutrition of girls is the strongest.

It is reassuring to see that two outcomes (weight for height and height for age) and two different strategies lead to the same results. Nevertheless, these results could also be tainted by failures of the identification assumption, which I now consider.

\subsection{Caveats and Specification Checks}

The comparison between old and young children in eligible and non-eligible families helps address some of the earlier concerns. In particular, any difference between eligible and non-eligible households that affects young and old children in a similar way is controlled for. However, there could still be age-specific differences in nutritional status across households.

\subsection{Endogenous Household Formation}

As discussed above, family composition may have changed as a result of the program, and this could invalidate the identification strategy proposed in this paper, if families where children are more (or less) likely to send their children to live with their grandparents or to have the grandparents with them. If this did not depend on the age of the child, this would not invalidate 
the spirit of the strategy. But it is conceivable that the correlation between child health and household composition is different for children aged 0 to 2 than for children aged 2 to 5 .

To address this problem, I use an alternative instrument, which is correlated with the presence of an eligible member in the household, but not affected by household decisions. This instrument is a variable that indicates whether the child has at least one grandparent who is alive and eligible, or likely to be eligible. The survey instrument asks household members whether their parents are alive. This makes it possible to determine whether the child has at least one living grandparent, but not to establish whether the grandparent is eligible (unless he or she lives in the household). However, if the mother and father are old enough their parents (if alive) are only likely to be eligible. In practice, the instrument is equal to 1 if there is an eligible person in the household or if one of the following is true: the mother (the father) of the child is older than 34 and her (his) mother is alive or the mother (the father) of the child is older than 32 and her (his) father is alive. ${ }^{17}$ Of children who have an old grandparent alive, $46 \%$ live with a pension recipient. Therefore this instrument is still strongly correlated with pension receipt. We can use it as an alternative instrument for pension receipt, and check whether results are consistent with those obtained using eligibility. This variable will also capture possible changes in transfers by (or to) a non co-resident grandparent, which, as shown by Jensen (1998), were affected by the pension. ${ }^{18}$

Most children (90\%) have at least one living grandparent. The variation in the instrument comes therefore mostly from parents' age. Children who have older parents may either be children who have many siblings or children whose parents had children later in life, which would have opposite consequences on their welfare. The two sub-samples (where this instrument is 0 or 1) are more similar to each other than eligible and non-eligible households are. This is apparent in the descriptive statistics presented in table 2 (columns 7 and 8). Two sets of characteristics are different: The child's parents are on average older and family size is on average larger when the child has an elderly grandparent. This increased similarity is reflected in their height in panel C. The difference in height for age between children is -0.04 (against -0.21 between

\footnotetext{
${ }^{17}$ I determined the cutoffs of 32 and 34 years by using the information on extended families in my sample. Women whose observed child is above 34 and men whose observed child is above 32 have a probability of $60 \%$ to be eligible for the pension. Results are not sensible to the choice of the cutoff. If a parent is not in the household, the survey does not indicate his age, or whether his parents are alive. So some children may have an old grandparent alive not identified in my data.

${ }^{18}$ Jensen (1998) shows that inter-generational transfers responded to the program. Transfers from children to parents were reduced when parents became eligible.
} 
eligible woman and no eligible member). The difference in differences estimator will control for systematic differences in the two groups which are fixed across cohorts, and is not affected by endogenous family formation.

Estimates of a difference in differences specification similar to the reduced form equation 4 , but where I use the indicator for whether the child has an elderly grandparent alive instead of eligibility status are presented in table 6 (column 5). For girls, there is a positive, significant at $15 \%$ only, effect of having an old grandmother alive, smaller than the estimated effect of woman's eligibility. This is expected, since the probability of getting the pension is higher for those living with an eligible member than for those who have an elderly grandparent alive. The effect of having an elderly grandfather alive is small and insignificant. For boys, there is no effect of having an old grandfather or an elderly grandmother alive.

We can then compute 2SLS estimates of the effect of pension receipt, (equation 5) using the interactions between the indicators for having an elderly grandfather or grandmother alive and being born after January 1992 as instruments. The first stages are shown in table A in the appendix (columns (5) and (6)). These instruments are still strongly correlated with the probability of receiving a pension. The coefficients are 0.40 for the relationship between woman's pension and elderly grandmother alive, and 0.22 for the relationship between man's pension and elderly grandfather alive. The instrumental variables estimate of the effect of the woman's and man's pension, using this instrument, is shown in columns (2) and (4) in table 7. Again, the only substantial point estimate is found for the effect of woman's pension on girls' height for age. The point estimate is 1.06 , very close to 1.16 which we estimated using eligibility as the instrument, but it is significant at $15 \%$ only.

In summary, using this alternative instrument leads to a reduced precision, but it does not change the conclusions, and confirms that previous results were not an artifact of endogenous household formation.

\subsubsection{Unobserved Characteristics of Government Programs}

Could these results be explained by age-specific differences between the nutritional status of children living in households where there is a woman eligible and that of children living in other households?

Younger girls are taller in households where there is an eligible woman. When I estimate the effect of eligibility on weight for height (equation 2) separately for young and old girls, the coefficients of woman's pension are respectively 0.71 and 0.56 . Both numbers are significantly 
different from 0 , but not from each other. These results are therefore unlikely to be driven by the fact that all children receive worse nutrition when they live with an eligible grandmother, but that the effects are stronger for older children. The fact that the effects on the weight for height of younger and older children are similar suggests that the results are not due to a program targeted towards young eligible children.

Similar results, however, would be obtained if children (old and young) living with eligible grandmothers were also more likely to be the target of other nutrition or government health programs. There were two nutritional programs in place at the time in South Africa (Budlender (2000)). The first was the Protein Energy Malnutrition scheme, in place since the 1960's, that subsidized the purchase of powdered skim milk for distribution to malnourished pre-school children at clinic. The program was modified and expanded in mid-1993. ${ }^{19}$ Since children born later than July 1993 are not in the sample, the expansion would not affect our sample. The second, the National Development Program (subsequently renamed the National Nutrition and Social

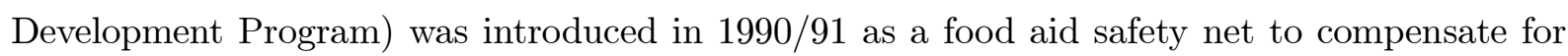
the planned introduction of the VAT on basic foodstuff, with a budget of R400 million annually. It was a program of food distribution (not particularly child focused), implemented at the local level through NGOs and community based organizations. Because of its decentralized implementation, it is not possible to document which households benefited more from this program, but eligible families are generally poorer, and therefore more likely to have been in the target groups of these NGOs. ${ }^{20}$

Three pieces of evidence suggest that these programs do not account for the results. First, the characteristics of families with eligible women and eligible men are very similar. It is therefore difficult to imagine that a program would have targeted disproportionately children living with their grandmothers, rather than all children living in extended families. Of course, one can imagine that grandmothers would be more likely to take advantage of these programs than grandfathers. However, the interaction between age and the presence of a woman above 50 (but not eligible) has the same coefficient as that of the presence of man above 50, which does not support this alternative explanation. Second, the regressions control for a range of observed household variables interacted with age dummies, and should therefore capture the effect of any program targeted according to these variables. After controlling for these variables, older children are not significantly smaller in eligible families, and therefore less likely to have been the

\footnotetext{
${ }^{19}$ Its budget was multiplied by 8 (to R40 Million annually) and it the target group was made wider.

${ }^{20}$ The largest existing nutrition program to date is the Primary School Nutrition Program, a Presidential Lead Project which was announced at the opening of the first democratic parliament in 1994.
} 
target of other programs. Finally, the point estimates I obtain with the alternative instruments (grandmother or grandfather alive and old) are very similar to those obtained using eligibility variables as instruments. The characteristics of families where children have a grandmother alive look very similar to those of children who do not have one. Therefore, it is unlikely that they would have been subject to different programs.

\section{Alternative Interpretation: Permanent Income}

The evidence therefore seems to indicate that a pension received by a woman had a large effect on child nutrition, while pension received by a man did not. However, two interpretations of this difference are possible. The first interpretation is that the same resources are spent differently when they are received by a woman and when they are received by a man. Another interpretation, however, could be that, in terms of permanent income, a rand of pension received by a man represents much less than a rand of pension received by a woman, because men are expected to receive the pension for a shorter time. It could lead to different effects of man's and woman's pension, if households have an ability to smooth consumption over time through savings or borrowing.

To help discriminate between these two interpretations, it is useful to look at the disposition of men's and women's pension income. If the household is a unitary entity, and if a man's pension income is not spent on child health because it is akin to transitory income, then we should see that the propensity to save out of man's income is much larger than the propensity to save out of woman's income (and non-pension income). I therefore estimate the following equation:

$$
S_{h}=\alpha_{f} y_{h f}+\alpha_{m} y_{h m}+\alpha z_{h}+X_{h} \beta+\epsilon_{h},
$$

where $S_{h}$ stands for the total savings of households (defined as total income minus expenditures), $y_{h f}$ is pension income received by woman, $y_{h m}$ is pension income received by man, $z_{h}$ is nonpension income, and $X_{h}$ is a set of control variables. This specification extends the Case and Deaton (1998) formulation to take into account differences in the disposition of income received by men and women. The emphasis here is on the comparison between $\alpha_{w}$ and $\alpha_{m}$. This equation is estimated by OLS, and 2SLS. The instruments in the 2SLS equations ( $y_{h f}, y_{h m}$, and $z_{h}$ are instrumented) are the indicators for the presence of an eligible man and an eligible woman, and the instruments used to correct for measurement errors in non-pension income, which are listed as a note to table 9 . 
Results are presented in table 9 (columns 1 and 2). The point estimates suggest that the propensity to save out of a man's pension income is actually lower than the propensity to save out of a woman's non-pension income (although this difference is not significant). This result indicates that the differences in the effects of woman's and man's pension income on child height is not likely to be due to their different life cycle properties. In combination with the results in the previous subsection, this result therefore suggests that the disposition of income is influenced by the gender of the recipient.

\section{Conclusion}

The extension of the Old Age Pension program in South Africa has led to an improvement in the health and nutrition of girls. This is reflected in the weight for height of all girls, and the height for age of the youngest girls. It had no discernible effect on boys. This effect is entirely due to pensions received by women.

I estimate that a pension received by a woman improved the height for age Z-scores of girls by at least 1.16 standard deviations, and their weight for height Z-scores by 1.19 standard deviations. South African girls are on average 1.20 standard deviations smaller than American children, so the estimates suggest that a pension received by a woman helped the girls bridge the entire gap in stature with American children.

The pension represented a large income transfer (it was equal to twice the median income per capita for rural South African households), so finding large effects on child health would perhaps not seem so surprising. Still, the fact that pensions received by women led to a sizeable increase in the height of girls shows that cash transfers can have an important effect on child health. There is almost no evidence of this kind in developing countries ${ }^{21}$ but the available evidence suggests that, in the U.S., cash transfers do not have substantial effects on child welfare (Mayer (1997), Currie (1995)). ${ }^{22}$ One would expect these effects to be larger in developing countries, where households are more likely to be credit constrained, and this study confirms this intuition.

Of course, the findings of this paper cannot be easily generalized to other developing countries. The program was on such a large scale that it could not be replicated outside of the very

\footnotetext{
${ }^{21}$ An exception is Carvalho (2000), who shows that an expansion of old age pension in Brazil led to an increase in educational attainment of girls, and to a decrease in child labor for boys.

${ }^{22}$ Shea (1997) studies whether children's outcomes (education and subsequent labor earnings) are correlated with their father's union status, job loss, or industry and finds no effect of these variables on child outcomes, except among the poorest families.
} 
particular context of the post-Apartheid era in South-Africa. There could be non linearity in the effects cash transfer, which makes it difficult to infer what the effect would have been had it been implemented on a different scale.

The most important result of the paper may then be that this very large cash transfer had no effect if it was received by a man. This strongly rejects the unitary model of the household, and suggests that the efficiency consequences of transfer programs may be of different order of magnitude depending on how they are administered. In South Africa, the program is naturally biased toward women, both because men can in principle claim the pension only after age 65 and because women tend to live longer. Without this feature, the program would not affect the nutrition of young children as much. The distinction between men and women is not in accordance with the South African constitution, and there is some pressure to remove it. The effectiveness of the pension program as a tool to transfer resources to young children would suggest moving in the opposite direction. Note however that other dimensions of investment in child human capital that we are not measuring here (education for example) could be affected by pensions received by men, so that this implication needs to be taken carefully. Future work should investigate whether the difference between men and women, and between girls and boys, is also found for other outcomes. It is also important to understand the reason for the larger effect on girls. Is it because they were lagging further behind? Is is specific to income received by grandmothers? Why do grandmothers prefer girls?

\section{References}

Ashworth, Ann (1969) 'Growth rates in children recovering from protein-calorie malnutrition.' British Journal of Nutrition 23, 835-845

Balazs, R., T. Jordan, P.D. Lewis, and A. J. Patel (1986) 'Undernutrition and brain development.' In Human Growth, ed. F. Falkner and J.M. Tanner, vol. 3 (Plenum Press) pp. 415474

Barker, D.J.P. (1990) 'The fetal and infant origins of adult disease.' British Medical Journal 301,1111

Berhman, Jere R., Robert A. Pollak, and P. Taubman (1995) From Parent to Child: Inequality and Immobility in the United States (University of Chicago Press) 
Bertrand, Marianne, Douglas Miller, and Sendhil Mullainathan (1999) 'Public policy and extended families: Evidence from South Africa.' Mimeo, MIT and Princeton

Bourguignon, François, Martin Browning, Pierre-Andre Chiappori, and Valerie Lechene (1994) 'Income and outcomes: A structural model of intrahousehold allocations.' Journal of Political Economy 102, 1067-1096

Browning, Martin, and Pierre-Andre Chiappori (1998) 'Efficient intra-household allocations: A general characterization and empirical tests.' Econometrica 66(6), 1241-1278

Budlender, Debbie (2000) Poverty and Inequality in South Africa: Meeting the Challenge (Zed Books)

Carvalho, Irineu (2000) 'Household income as a determinant of child labor and school enrollment in Brazil: Evidence from a social security reform.' Mimeo, MIT

Case, Anne, and Angus Deaton (1998) 'Large cash transfers to the elderly in South Africa.' Economic Journal 108(450), 1330-61

Chiappori, Pierre-Andre (1988) 'Rational household labor supply.' Econometrica 56(1), 63-90

_ (1999) 'Labor supply and efficient risk-sharing.' Mimeo, University of Chicago

Currie, Janet (1995) Welfare and the Well-being of Children number 59. In 'Fundamentals of Pure and Applied Economics.' (Newark: Harwood Academic publishers)

Dasgupta, Partha (1993) Inquiry into Well-Being and Destitution (Oxford: Clarendon Press)

Foster, Andrew D. (1998) 'Marriage-market selection and human capital allocations in rural bangladesh.' Mimeo, University of Pennsylvania

Jensen, Robert (1998) 'Three essays on microeconomics and social policy in South Africa.' PhD dissertation, Princeton University

Le Roux, Pieter (1995) 'Poverty, social policies and the reconstruction and development programme.' Working Paper, Institute for Theological and Interdisciplinary Research

Lund, Frances (1993) 'State social benefits in South Africa.' International Social Security Review $46(1), 5-25$ 
Lundberg, Shelly J., Robert A. Pollak, and Terence J. Wales (1996) 'Do husbands and wives pool their resources? Evidence from the United Kingdom child benefit.' Journal of Human Resources 32(4), 463-480

Martorell, R., and J.P. Habicht (1986) 'Growth in early childhood in developing countries.' In Human Growth: A Comprehensive Treatise, ed. F. Falkner and J.M. Tanner, 2 ed., vol. 3 (New York: Plenum Press)

Mayer, Susan E. (1997) What Money Can't Buy: Family Income and Children's Life Chances (Cambridge: Harvard University Press)

Miguel, Edward, and Michael Kremer (1999) 'The educational impact of deworming in Kenya.' Mimeo, Harvard

Schultz, T. Paul (1999) 'Productive benefits of improving health: Evidence from low-income countries.' Mimeo

Scrimshaw, Nevin S. (1997) 'The relation between fetal malnutrition and chronic disease in later life.' British Medical Journal 315, 825-826

Shea, John (1997) 'Does parents' money matter?' Working Paper 6026, National Bureau of Economic Research

Strauss, John, and Duncan Thomas (1998) 'Health, nutrition, and economic development.' Journal of Economic Literature 36(2), 766-817

Thomas, Duncan (1990) 'Intra-household resource allocation: An inferential approach.' Journal of Human Resources 25(4), 635-664

Van der Berg, Servaas (1994) 'Issues in South African social security.' World Bank-IFC-MIGA Office Memorandum

WHO, Working Group (1986) 'Use and interpretation of anthropometric indicators of nutritional status.' Bulletin of the World Health Organization 64(6), 929-941 
Figure 1: Height for age of children living with eligible womenn, eligible men, no eligible member

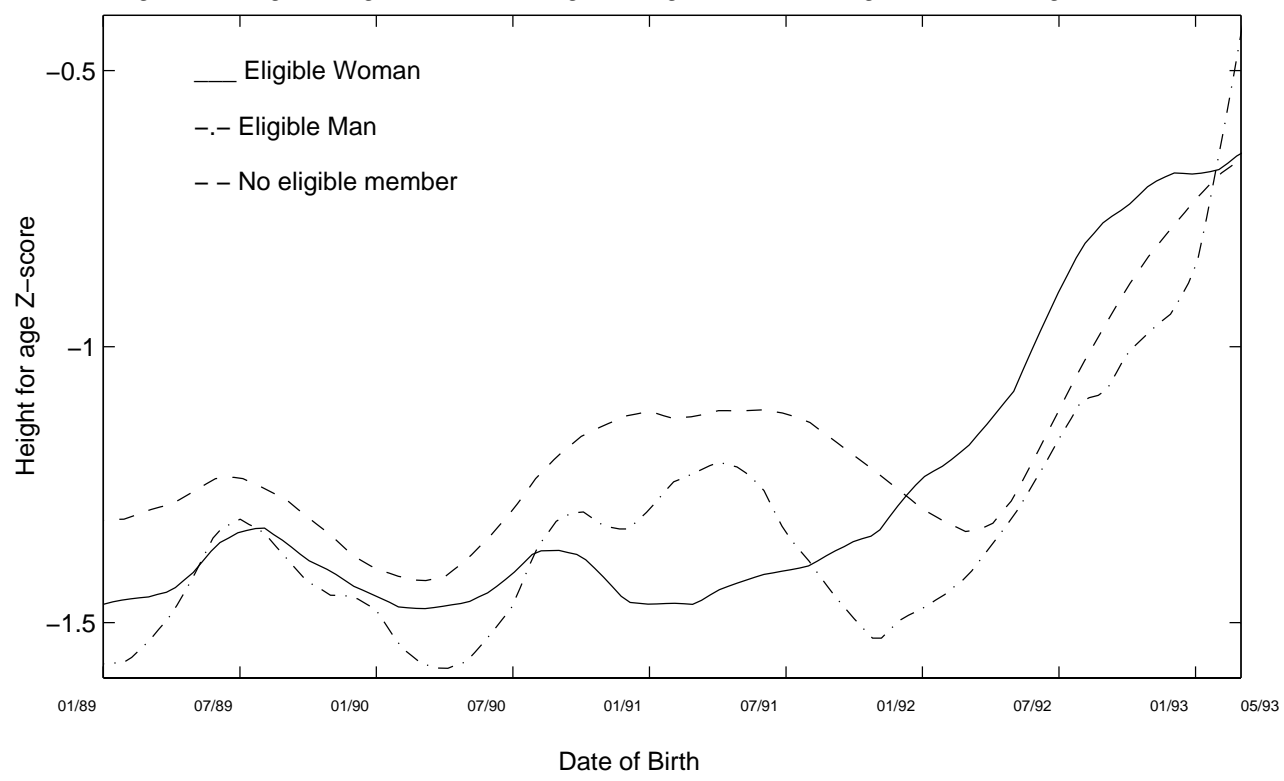


Table 1: Probability of receiving the pension, by age and gender

\begin{tabular}{cc}
\hline \hline Percentage \\
receiving pension \\
$(1993)$
\end{tabular}

PANEL A: Men

Age in 1993

$50-54$

2.8

$55-59$

4.7

$60-64$

22

65 and above

60

PANEL B: Women

Age in 1993

$50-54$

13.6

55-59

16.4

60 and above

77 
Table 2: Descriptive statistics

\begin{tabular}{|c|c|c|c|c|c|c|c|c|}
\hline & \multicolumn{3}{|c|}{ Receipt of pension } & \multicolumn{3}{|c|}{ Eligibility for pension } & \multicolumn{2}{|c|}{ Grandparent alive and old } \\
\hline & Woman & Man & None & Woman & Man & None & Yes & No \\
\hline & $(1)$ & (2) & (3) & (4) & $(5)$ & (6) & (7) & $(8)$ \\
\hline \multicolumn{9}{|c|}{ PANEL A: HOUSEHOLD CHARACTERISTICS } \\
\hline Father's age & $\begin{array}{r}34.8 \\
(0.80)\end{array}$ & $\begin{array}{r}38.5 \\
(1.89)\end{array}$ & $\begin{array}{r}37.0 \\
(0.38)\end{array}$ & $\begin{array}{r}35.5 \\
(0.79)\end{array}$ & $\begin{array}{r}40.9 \\
(2.10)\end{array}$ & $\begin{array}{r}36.8 \\
(0.37)\end{array}$ & $\begin{array}{r}38.9 \\
(0.43)\end{array}$ & $\begin{array}{r}33.1 \\
(0.59)\end{array}$ \\
\hline Mother's age & $\begin{array}{r}27.8 \\
(0.38)\end{array}$ & $\begin{array}{r}27.6 \\
(0.60)\end{array}$ & $\begin{array}{r}29.6 \\
(0.20)\end{array}$ & $\begin{array}{r}28.2 \\
(0.38)\end{array}$ & $\begin{array}{r}27.5 \\
(0.58)\end{array}$ & $\begin{array}{r}29.5 \\
(0.20)\end{array}$ & $\begin{array}{r}31.4 \\
(0.24)\end{array}$ & $\begin{array}{r}26.5 \\
(0.24)\end{array}$ \\
\hline $\begin{array}{l}\text { Mother's } \\
\text { education }\end{array}$ & $\begin{array}{r}5.65 \\
(0.16)\end{array}$ & $\begin{array}{r}5.82 \\
(0.24)\end{array}$ & $\begin{array}{r}5.19 \\
(0.085)\end{array}$ & $\begin{array}{r}5.70 \\
(0.16)\end{array}$ & $\begin{array}{r}5.78 \\
(0.24)\end{array}$ & $\begin{array}{r}5.17 \\
(0.086)\end{array}$ & $\begin{array}{r}5.08 \\
(0.11)\end{array}$ & $\begin{array}{r}5.63 \\
(0.11)\end{array}$ \\
\hline $\begin{array}{l}\text { Father's } \\
\text { education }\end{array}$ & $\begin{array}{r}4.99 \\
(0.29)\end{array}$ & $\begin{array}{r}5.08 \\
(0.45)\end{array}$ & $\begin{array}{r}4.52 \\
(0.11)\end{array}$ & $\begin{array}{r}5.07 \\
(0.27)\end{array}$ & $\begin{array}{r}4.20 \\
(0.46)\end{array}$ & $\begin{array}{r}4.54 \\
(0.11)\end{array}$ & $\begin{array}{r}4.62 \\
(0.14)\end{array}$ & $\begin{array}{r}4.76 \\
(0.17)\end{array}$ \\
\hline Rural residence & $\begin{array}{r}0.75 \\
(0.019)\end{array}$ & $\begin{array}{r}0.79 \\
(0.029)\end{array}$ & $\begin{array}{r}0.67 \\
(0.012)\end{array}$ & $\begin{array}{r}0.75 \\
(0.018)\end{array}$ & $\begin{array}{r}0.83 \\
(0.028)\end{array}$ & $\begin{array}{r}0.67 \\
(0.012)\end{array}$ & $\begin{array}{r}0.70 \\
(0.014)\end{array}$ & $\begin{array}{r}0.67 \\
(0.015)\end{array}$ \\
\hline $\begin{array}{l}\text { Grandparent in } \\
\text { household }\end{array}$ & $\begin{array}{r}0.95 \\
(0.008)\end{array}$ & $\begin{array}{r}0.88 \\
(0.022)\end{array}$ & $\begin{array}{r}0.42 \\
(0.012)\end{array}$ & $\begin{array}{r}0.95 \\
(0.0081)\end{array}$ & $\begin{array}{r}0.89 \\
(0.021)\end{array}$ & $\begin{array}{r}0.42 \\
(0.012)\end{array}$ & $\begin{array}{r}0.56 \\
(0.014)\end{array}$ & $\begin{array}{r}0.56 \\
(0.015)\end{array}$ \\
\hline $\begin{array}{l}\text { Father is } \\
\text { absent }\end{array}$ & $\begin{array}{r}0.64 \\
(0.020)\end{array}$ & $\begin{array}{r}0.66 \\
(0.031)\end{array}$ & $\begin{array}{r}0.42 \\
(0.012)\end{array}$ & $\begin{array}{r}0.67 \\
(0.020)\end{array}$ & $\begin{array}{r}0.66 \\
(0.033)\end{array}$ & $\begin{array}{r}0.41 \\
(0.012)\end{array}$ & $\begin{array}{r}0.41 \\
(0.014)\end{array}$ & $\begin{array}{r}0.55 \\
(0.015)\end{array}$ \\
\hline $\begin{array}{l}\text { Mother is } \\
\text { absent }\end{array}$ & $\begin{array}{r}0.18 \\
(0.016)\end{array}$ & $\begin{array}{r}0.18 \\
(0.026)\end{array}$ & $\begin{array}{r}0.08 \\
(0.0059)\end{array}$ & $\begin{array}{r}0.18 \\
(0.016)\end{array}$ & $\begin{array}{r}0.14 \\
(0.023)\end{array}$ & $\begin{array}{r}0.08 \\
(0.0059)\end{array}$ & $\begin{array}{r}0.10 \\
(0.0082)\end{array}$ & $\begin{array}{r}0.11 \\
(0.0089)\end{array}$ \\
\hline $\begin{array}{l}\text { Father is } \\
\text { dead }\end{array}$ & $\begin{array}{r}0.059 \\
(0.0099)\end{array}$ & $\begin{array}{r}0.0067 \\
(0.0050)\end{array}$ & $\begin{array}{r}0.030 \\
(0.0040)\end{array}$ & $\begin{array}{r}0.038 \\
(0.0076)\end{array}$ & $\begin{array}{r}0.037 \\
(0.0039)\end{array}$ & $\begin{array}{r}0.034 \\
(0.0043)\end{array}$ & $\begin{array}{l}0.036 \\
(0.05)\end{array}$ & $\begin{array}{r}0.037 \\
(0.0059)\end{array}$ \\
\hline $\begin{array}{l}\text { Mother is } \\
\text { dead }\end{array}$ & $\begin{array}{r}0.011 \\
(0.004)\end{array}$ & $\begin{array}{r}0.0039 \\
(0.0044)\end{array}$ & $\begin{array}{r}0.0051 \\
(0.0016)\end{array}$ & $\begin{array}{r}0.0098 \\
(0.0037)\end{array}$ & $\begin{array}{r}0.0072 \\
(0.0017)\end{array}$ & $\begin{array}{r}0.0058 \\
(0.0017)\end{array}$ & $\begin{array}{r}0.0053 \\
(0.0019)\end{array}$ & $\begin{array}{r}0.0088 \\
(0.0027)\end{array}$ \\
\hline Household size & $\begin{array}{r}9.2 \\
(0.17)\end{array}$ & $\begin{array}{r}8.9 \\
(0.22)\end{array}$ & $\begin{array}{r}7.8 \\
(0.093)\end{array}$ & $\begin{array}{r}10.5 \\
(0.21)\end{array}$ & $\begin{array}{r}10.5 \\
-0.3\end{array}$ & $\begin{array}{r}7.6 \\
(0.086)\end{array}$ & $\begin{array}{r}8.7 \\
(0.13)\end{array}$ & $\begin{array}{r}7.7 \\
(0.11)\end{array}$ \\
\hline \multicolumn{9}{|c|}{ PANEL B: PENSION RECEIPT } \\
\hline $\begin{array}{l}\text { Male receives } \\
\text { pension }\end{array}$ & $\begin{array}{r}0.18 \\
(0.017)\end{array}$ & 1 & 0 & $\begin{array}{r}0.17 \\
(0.016)\end{array}$ & $\begin{array}{r}0.68 \\
(0.034)\end{array}$ & $\begin{array}{r}0.03 \\
(0.0041)\end{array}$ & $\begin{array}{r}0.14 \\
(0.011)\end{array}$ & $\begin{array}{r}0.04 \\
(0.0059)\end{array}$ \\
\hline $\begin{array}{l}\text { Female receives } \\
\text { pension }\end{array}$ & 1 & $\begin{array}{r}0.47 \\
(0.035)\end{array}$ & 0 & $\begin{array}{r}0.79 \\
(0.018)\end{array}$ & $\begin{array}{r}0.47 \\
(0.037)\end{array}$ & $\begin{array}{r}0.04 \\
(0.0050)\end{array}$ & $\begin{array}{r}0.40 \\
(0.014)\end{array}$ & $\begin{array}{r}0.05 \\
(0.0068)\end{array}$ \\
\hline $\begin{array}{l}\text { Non-pension } \\
\text { income }\end{array}$ & $\begin{array}{l}691 \\
(37)\end{array}$ & $\begin{array}{r}573 \\
(49)\end{array}$ & $\begin{array}{l}927 \\
(22)\end{array}$ & $\begin{array}{l}723 \\
(36)\end{array}$ & $\begin{array}{r}637 \\
(51)\end{array}$ & $\begin{array}{l}908 \\
(22)\end{array}$ & $\begin{array}{l}813 \\
(24)\end{array}$ & $\begin{array}{l}885 \\
(29)\end{array}$ \\
\hline Pension income & $\begin{array}{r}395 \\
(7.77)\end{array}$ & $\begin{array}{l}489 \\
(15)\end{array}$ & 0 & $\begin{array}{r}325 \\
(9.6)\end{array}$ & $\begin{array}{l}389 \\
(20)\end{array}$ & $\begin{array}{r}23 \\
(2.2)\end{array}$ & $\begin{array}{r}182 \\
(6.7)\end{array}$ & $\begin{array}{r}27 \\
(3.2)\end{array}$ \\
\hline $\begin{array}{l}\text { Per-capita } \\
\text { income }\end{array}$ & $\begin{array}{r}125 \\
(4.37)\end{array}$ & $\begin{array}{r}127 \\
(6.47)\end{array}$ & $\begin{array}{r}148 \\
(3.9)\end{array}$ & $\begin{array}{r}121 \\
(4.5)\end{array}$ & $\begin{array}{r}123 \\
(7.3)\end{array}$ & $\begin{array}{r}149 \\
(3.9)\end{array}$ & $\begin{array}{r}146 \\
(4.3)\end{array}$ & $\begin{array}{r}143 \\
(4.7)\end{array}$ \\
\hline \multicolumn{9}{|c|}{ PANEL C: ANTHROPOMETRIC DATA } \\
\hline $\begin{array}{l}\text { Height for age } \\
\text { Z-score }\end{array}$ & $\begin{array}{r}-1.41 \\
(0.075)\end{array}$ & $\begin{array}{r}-1.44 \\
(0.13)\end{array}$ & $\begin{array}{r}-1.2 \\
(0.036)\end{array}$ & $\begin{array}{r}-1.38 \\
(0.072)\end{array}$ & $\begin{array}{r}-1.46 \\
(0.13)\end{array}$ & $\begin{array}{r}-1.21 \\
(0.036)\end{array}$ & $\begin{array}{r}-1.28 \\
(0.046)\end{array}$ & $\begin{array}{r}-1.23 \\
(0.045)\end{array}$ \\
\hline $\begin{array}{l}\text { Weight for age } \\
\text { Z-score }\end{array}$ & $\begin{array}{r}0.19 \\
(0.08)\end{array}$ & $\begin{array}{l}-0.02 \\
(0.13)\end{array}$ & $\begin{array}{r}0.16 \\
(0.04)\end{array}$ & $\begin{array}{r}0.28 \\
(0.08)\end{array}$ & $\begin{array}{r}0.12 \\
(0.15)\end{array}$ & $\begin{array}{r}0.15 \\
(0.04)\end{array}$ & $\begin{array}{r}0.12 \\
(0.05)\end{array}$ & $\begin{array}{r}0.21 \\
(0.05)\end{array}$ \\
\hline N. Obs. & 766 & 294 & 2404 & 816 & 286 & 2380 & 1768 & 1562 \\
\hline
\end{tabular}

Notes: Standard errors in parentheses.

For household level variables, the table presents household averages weighted by the number of children in each household (multiplied by survey weights). For anthropometric data, the table presents individual level averages. 
Table 3: Descriptive statistics by age group, height for age

\begin{tabular}{|c|c|c|c|c|c|c|}
\hline & $\begin{array}{l}\text { Woman } \\
\text { receives } \\
\text { pension }\end{array}$ & $\begin{array}{c}\text { Man } \\
\text { receives } \\
\text { pension }\end{array}$ & No pension & $\begin{array}{l}\text { Woman } \\
\text { eligible }\end{array}$ & $\begin{array}{l}\text { Man } \\
\text { eligible }\end{array}$ & $\begin{array}{c}\text { No eligible } \\
\text { member }\end{array}$ \\
\hline & $(1)$ & $(2)$ & (3) & $(4)$ & $(5)$ & $(6)$ \\
\hline \multicolumn{7}{|l|}{ Panel A: Boys } \\
\hline Born $01 / 92$ or later & $\begin{array}{l}-1.40 \\
(0.20)\end{array}$ & $\begin{array}{l}-1.61 \\
(0.36)\end{array}$ & $\begin{array}{l}-1.19 \\
(0.11)\end{array}$ & $\begin{array}{l}-1.26 \\
(0.20)\end{array}$ & $\begin{array}{l}-1.87 \\
(0.38)\end{array}$ & $\begin{array}{l}-1.20 \\
(0.11)\end{array}$ \\
\hline Born before $01 / 92$ & $\begin{array}{l}-1.64 \\
(0.12)\end{array}$ & $\begin{array}{l}-1.60 \\
(0.19)\end{array}$ & $\begin{array}{c}-1.33 \\
(0.055)\end{array}$ & $\begin{array}{l}-1.60 \\
(0.11)\end{array}$ & $\begin{array}{l}-1.61 \\
(0.18)\end{array}$ & $\begin{array}{l}-1.32 \\
(0.05)\end{array}$ \\
\hline \multicolumn{7}{|l|}{ Panel B: Girls } \\
\hline Born $01 / 92$ or later & $\begin{array}{l}-0.57 \\
(0.24)\end{array}$ & $\begin{array}{l}-1.11 \\
(0.36)\end{array}$ & $\begin{array}{l}-0.93 \\
(0.11)\end{array}$ & $\begin{array}{l}-0.64 \\
(0.23)\end{array}$ & $\begin{array}{l}-0.86 \\
(0.42)\end{array}$ & $\begin{array}{l}-0.94 \\
(0.11)\end{array}$ \\
\hline Born before $01 / 92$ & $\begin{array}{l}-1.47 \\
(0.12)\end{array}$ & $\begin{array}{l}-1.37 \\
(0.22) \\
\end{array}$ & $\begin{array}{l}-1.24 \\
(0.06)\end{array}$ & $\begin{array}{l}-1.52 \\
(0.12)\end{array}$ & $\begin{array}{l}-1.34 \\
(0.22) \\
\end{array}$ & $\begin{array}{l}-1.25 \\
(0.06)\end{array}$ \\
\hline
\end{tabular}

Note: Standard errors in parentheses 
Table 4: Effect of the program on weight for height

OLS and 2SLS regressions

\begin{tabular}{|c|c|c|c|c|c|c|c|}
\hline & \multicolumn{7}{|c|}{ Dependent variable: Weight for Height Z-score } \\
\hline & \multicolumn{6}{|c|}{ OLS } & \multirow{2}{*}{$\begin{array}{c}\text { 2SLS } \\
(7) \\
\end{array}$} \\
\hline & $(1)$ & $(2)$ & (3) & (4) & (5) & (6) & \\
\hline \multicolumn{8}{|l|}{ Panel A: Boys } \\
\hline Eligible household & $\begin{array}{c}0.0012 \\
(0.13)\end{array}$ & $\begin{array}{l}0.022 \\
(0.22)\end{array}$ & $\begin{array}{l}0.030 \\
(0.24)\end{array}$ & & & & \\
\hline $\begin{array}{l}\text { Woman eligible } \\
\text { (in col. 7: woman receives pension) }\end{array}$ & & & & $\begin{array}{l}0.066 \\
(0.14)\end{array}$ & $\begin{array}{c}0.28 \\
(0.28)\end{array}$ & $\begin{array}{c}0.31 \\
(0.28)\end{array}$ & $\begin{array}{c}0.58 \\
(0.53)\end{array}$ \\
\hline $\begin{array}{l}\text { Man eligible } \\
\text { (in col. 7: man receives pension) }\end{array}$ & & & & $\begin{array}{l}-0.059 \\
(0.22)\end{array}$ & $\begin{array}{l}-0.25 \\
(0.34)\end{array}$ & $\begin{array}{l}-0.25 \\
(0.35)\end{array}$ & $\begin{array}{l}-0.69 \\
(0.91)\end{array}$ \\
\hline Woman above 50 & & $\begin{array}{c}-0.090 \\
(0.20)\end{array}$ & $\begin{array}{l}-0.13 \\
(0.33)\end{array}$ & & $\begin{array}{l}-0.10 \\
(0.20)\end{array}$ & $\begin{array}{l}-0.13 \\
(0.32)\end{array}$ & $\begin{array}{c}0.14 \\
(0.32)\end{array}$ \\
\hline Man above 50 & & $\begin{array}{c}0.11 \\
(0.24)\end{array}$ & $\begin{array}{c}0.19 \\
(0.31)\end{array}$ & & $\begin{array}{c}0.12 \\
(0.23)\end{array}$ & $\begin{array}{c}0.20 \\
(0.30)\end{array}$ & $\begin{array}{c}0.27 \\
(0.30)\end{array}$ \\
\hline Woman above 56 & & $\begin{array}{l}0.037 \\
(0.25)\end{array}$ & $\begin{array}{l}0.019 \\
(0.26)\end{array}$ & & $\begin{array}{l}-0.16 \\
(0.30)\end{array}$ & $\begin{array}{l}-0.18 \\
(0.31)\end{array}$ & $\begin{array}{l}-0.26 \\
(0.38)\end{array}$ \\
\hline Man above 56 & & $\begin{array}{c}0.18 \\
(0.33)\end{array}$ & $\begin{array}{r}0.0028 \\
(0.34)\end{array}$ & & $\begin{array}{c}0.19 \\
(0.24)\end{array}$ & $\begin{array}{l}0.014 \\
(0.34)\end{array}$ & $\begin{array}{l}0.025 \\
(0.34)\end{array}$ \\
\hline Man above 61 & & $\begin{array}{l}-0.19 \\
(0.33)\end{array}$ & $\begin{array}{l}-0.15 \\
(0.34)\end{array}$ & & $\begin{array}{l}-0.038 \\
(0.37)\end{array}$ & $\begin{array}{c}0.00098 \\
(0.38)\end{array}$ & $\begin{array}{c}0.17 \\
(0.52)\end{array}$ \\
\hline N. Obs & 1670 & 1670 & 1627 & 1670 & 1670 & 1627 & 1627 \\
\hline \multicolumn{8}{|l|}{ Panel B: Girls } \\
\hline Eligible household & $\begin{array}{c}0.14 \\
(0.12)\end{array}$ & $\begin{array}{l}0.35^{*} \\
(0.17)\end{array}$ & $\begin{array}{l}0.34^{*} \\
(0.17)\end{array}$ & & & & \\
\hline $\begin{array}{l}\text { Woman eligible } \\
\text { (in col. 7: woman receives pension) }\end{array}$ & & & & $\begin{array}{l}0.24^{*} \\
(0.12)\end{array}$ & $\begin{array}{l}0.61 * \\
(0.19)\end{array}$ & $\begin{array}{l}0.61 * \\
(0.19)\end{array}$ & $\begin{array}{l}1.19^{*} \\
(0.41)\end{array}$ \\
\hline $\begin{array}{l}\text { Man eligible } \\
\text { (in col. 7: man receives pension) }\end{array}$ & & & & $\begin{array}{l}-0.011 \\
(0.22)\end{array}$ & $\begin{array}{c}0.11 \\
(0.28)\end{array}$ & $\begin{array}{l}0.056 \\
(0.19)\end{array}$ & $\begin{array}{l}-0.097 \\
(0.74)\end{array}$ \\
\hline Woman above 50 & & $\begin{array}{c}0.17 \\
(0.17)\end{array}$ & $\begin{array}{l}0.067 \\
(0.24)\end{array}$ & & $\begin{array}{c}0.16 \\
(0.17)\end{array}$ & $\begin{array}{l}0.024 \\
(0.24)\end{array}$ & $\begin{array}{l}-0.066 \\
(0.24)\end{array}$ \\
\hline Man above 50 & & $\begin{array}{c}0.28 \\
(0.18)\end{array}$ & $\begin{array}{c}0.34 \\
(0.35)\end{array}$ & & $\begin{array}{c}0.28 \\
(0.18)\end{array}$ & $\begin{array}{c}0.29 \\
(0.25)\end{array}$ & $\begin{array}{c}0.30 \\
(0.25)\end{array}$ \\
\hline Woman above 56 & & $\begin{array}{l}-0.35 \\
(0.20)\end{array}$ & $\begin{array}{l}-0.36 \\
(0.21)\end{array}$ & & $\begin{array}{l}-0.55 \\
(0.21)\end{array}$ & $\begin{array}{l}-0.56 \\
(0.22)\end{array}$ & $\begin{array}{l}-0.71 \\
(0.26)\end{array}$ \\
\hline Man above 56 & & $\begin{array}{l}-0.40 \\
(0.24)\end{array}$ & $\begin{array}{l}-0.32 \\
(0.25)\end{array}$ & & $\begin{array}{l}-0.36 \\
(0.24)\end{array}$ & $\begin{array}{l}-0.27 \\
(0.25)\end{array}$ & $\begin{array}{l}-0.28 \\
(0.26)\end{array}$ \\
\hline Man above 61 & & $\begin{array}{c}-0.0098 \\
(0.22)\end{array}$ & $\begin{array}{l}0.048 \\
(0.23)\end{array}$ & & $\begin{array}{c}-0.0054 \\
(0.26)\end{array}$ & $\begin{array}{l}0.086 \\
(0.26)\end{array}$ & $\begin{array}{c}0.14 \\
(0.34)\end{array}$ \\
\hline N. Obs & 1574 & 1574 & 1533 & 1574 & 1574 & 1533 & 1533 \\
\hline Family background variables & No & No & Yes & No & No & Yes & Yes \\
\hline Age dummies & Yes & Yes & Yes & Yes & Yes & Yes & Yes \\
\hline
\end{tabular}

Notes: Standard errors (robust to correlation of residuals within households and heteroscedasticity) in parentheses.

Family background variables: father's age and education, mother's age and education and rural or metro residence.

Member age variables: family size, number of members aged 0 to 5, 6 to 15,15 to 24,24 to 49 .

Age dummies: Dummies for whether the child is born in 1991, 1990, or 1989.

The instruments in column (7) are woman eligible and man eligible (the first stage is in table A). 
Table 5: Effect of eligibility by gender of the intermediate generation. OLS regressions

\begin{tabular}{lcc}
\hline \hline & $\begin{array}{c}\text { Weight for height } \\
\text { BOYS } \\
(1)\end{array}$ & $\begin{array}{c}\text { Weight for height } \\
\text { GIRLS } \\
(1)\end{array}$ \\
& 0.099 & $0.48^{*}$ \\
& $(0.27)$ & $(0.21)$ \\
Mother's mother & & \\
eligible & 0.29 & 0.15 \\
& $(0.30)$ & $(0.25)$ \\
Father's mother & & \\
eligible & 0.00052 & 0.097 \\
Mother's father & $(0.43)$ & $(0.34)$ \\
eligible & & \\
& 0.25 & 0.22 \\
Father's father & $(0.44)$ & $(0.48)$ \\
eligible & & \\
& & \\
Control variables: & Yes & Yes \\
Presence of older members & Yes & Yes \\
Family background variables & Yes & 1457 \\
Age dummies & 1552 & \\
N. Obs. &
\end{tabular}

Notes: Standard errors (robust to correlation of residuals within households and heteroscedasticity) in parentheses.

Family background variables: father's age and education, mother's age and education and rural or metro residence.

family size, number of members aged 0 to 5,6 to 15,15 to 24,24 to 49 ,

Age dummies: Dummies for whether the child is born in 1991, 1990, or 1989.

Presence of older members: Dummies for whether there is a woman above 50, a man above 50, a woman above 55, a man above 55, a man above 60 . 
Table 6: Effect of eligibility on height for age.

OLS regressions

\begin{tabular}{|c|c|c|c|c|c|}
\hline & \multicolumn{5}{|c|}{ Dependent variable: Height for age Z-score } \\
\hline & (1) & (2) & (3) & (4) & (5) \\
\hline \multicolumn{6}{|l|}{ Panel A: Boys } \\
\hline Eligible household*YOUNG & $\begin{array}{c}0.17 \\
(0.26)\end{array}$ & $\begin{array}{c}0.11 \\
(0.31)\end{array}$ & & & \\
\hline Woman eligible *YOUNG & & & $\begin{array}{c}0.30 \\
(0.28)\end{array}$ & $\begin{array}{c}0.18 \\
(0.32)\end{array}$ & \\
\hline Man eligible*YOUNG & & & $\begin{array}{l}-0.44 \\
(0.39)\end{array}$ & $\begin{array}{c}-0.30 \\
(0.32)\end{array}$ & \\
\hline Old grandmother *YOUNG & & & & & $\begin{array}{l}0.026 \\
(0.27)\end{array}$ \\
\hline Old grandfather*YOUNG & & & & & $\begin{array}{c}0.18 \\
(0.30)\end{array}$ \\
\hline Eligible household & $\begin{array}{l}-0.27^{*} \\
(0.12)\end{array}$ & $\begin{array}{l}-0.15 \\
(0.15)\end{array}$ & & & \\
\hline Woman eligible & & & $\begin{array}{l}-0.24 \\
(0.13)\end{array}$ & & \\
\hline Man eligible & & & $\begin{array}{l}-0.16 \\
(0.19)\end{array}$ & & \\
\hline Old grandmother & & & & & $\begin{array}{c}-0.084 \\
(0.69)\end{array}$ \\
\hline Old Grandfather & & & & & $\begin{array}{c}-0.011 \\
(0.14)\end{array}$ \\
\hline N. Obs & 1670 & 1627 & 1670 & 1627 & 1627 \\
\hline
\end{tabular}

\section{Panel B: Girls}

Eligible household*YOUNG

$\begin{array}{cc}0.50 & 0.68^{*} \\ (0.27) & (0.37)\end{array}$

Woman eligible *YOUNG

$0.60 * \quad 0.71 *$

$(0.28) \quad(0.34)$

Man eligible*YOUNG

$-0.078 \quad 0.097$

$(0.51) \quad(0.57)$

Old grandmother *YOUNG

$(0.27)$

Old grandfather*YOUNG

$-0.12$

$(0.35)$

Eligible household

Woman eligible

$\begin{array}{cc}-0.26 & -0.15 \\ (0.14) & (0.17) \\ -0.083 & -0.11 \\ (0.23) & (0.24)\end{array}$

Old grandmother

$-0.039$

$(0.13)$

0.027

Old grandfather

$(0.15)$

N. Obs

1574

1533

1574

1533 1533

Notes: Standard errors (robust to correlation of residuals within households and heteroscedasticity) in parentheses.

Family background variables: father's age and education, mother's age and education and rural or metro residence, family size, number of members aged 0 to 5,6 to 15,15 to 24,24 to 49 , above 50 Age dummies: Dummies for whether the child is born in 1991, 1990,or 1989. 
Table 7: Effect of pension receipt on height for age.

2SLS regressions

\begin{tabular}{|c|c|c|c|c|}
\hline & \multicolumn{4}{|c|}{ Dependent variable: Height for age } \\
\hline & \multicolumn{2}{|c|}{ BOYS } & \multicolumn{2}{|c|}{ GIRLS } \\
\hline & $(1)$ & $(2)$ & $(3)$ & $(4)$ \\
\hline Woman receives pension $*$ YOUNG & $\begin{array}{c}0.28 \\
(0.47)\end{array}$ & $\begin{array}{l}0.084 \\
(0.62)\end{array}$ & $\begin{array}{l}1.16^{*} \\
(0.56)\end{array}$ & $\begin{array}{c}1.06 \\
(0.72)\end{array}$ \\
\hline Man receives pension * YOUNG & $\begin{array}{l}-0.47 \\
(0.71)\end{array}$ & $\begin{array}{c}0.70 \\
(1.11)\end{array}$ & $\begin{array}{c}-0.071 \\
(0.95)\end{array}$ & $\begin{array}{l}-0.63 \\
(1.62)\end{array}$ \\
\hline Woman eligible & $\begin{array}{l}-0.15 \\
(0.17)\end{array}$ & & $\begin{array}{c}-0.15 \\
(0.17)\end{array}$ & \\
\hline Man eligible & $\begin{array}{l}-0.057 \\
(0.21)\end{array}$ & & $\begin{array}{c}-0.11 \\
(0.24)\end{array}$ & \\
\hline Old grandmother & & $\begin{array}{c}-0.084 \\
(0.12)\end{array}$ & & $\begin{array}{l}0.029 \\
(0.15)\end{array}$ \\
\hline Old grandfather & & $\begin{array}{c}-0.011 \\
(0.14)\end{array}$ & & $\begin{array}{c}-0.038 \\
(0.13)\end{array}$ \\
\hline \multicolumn{5}{|l|}{ Control variables: } \\
\hline Presence of older members & Yes & Yes & Yes & Yes \\
\hline Family Background variable & Yes & Yes & Yes & Yes \\
\hline Age dummies & Yes & Yes & Yes & Yes \\
\hline N. Obs. & 1627 & 1627 & 1533 & 1533 \\
\hline
\end{tabular}

Notes: Standard errors (robust to correlation of residuals within households and heteroscedasticity) in parentheses.

Family background variables: father's age and education, mother's age and education and rural or metro residence, family size, number of members aged 0 to 5,6 to 15,15 to 24,24 to 49 , above 50 Age dummies: Dummies for whether the child is born in 1991, 1990, or 1989.

The instruments in column (1) and (3) are the interactions woman eligible*YOUNG and man eligible*YOUNG. The instruments in column (2) and (4) are the interactions old grandmother*YOUNG and old grandfather*YOUNG 
Table 8: Effect of eligibility on height for age, by gender of the intermediate generation. OLS regressions

\begin{tabular}{|c|c|c|}
\hline & $\begin{array}{c}\text { BOYS } \\
(1)\end{array}$ & $\begin{array}{c}\text { GIRLS } \\
(3)\end{array}$ \\
\hline Mother's mother eligible * YOUNG & $\begin{array}{c}0.23 \\
(0.51)\end{array}$ & $\begin{array}{c}0.94 \\
(0.56)\end{array}$ \\
\hline Father's mother eligible * YOUNG & $\begin{array}{l}-0.34 \\
(0.54)\end{array}$ & $\begin{array}{c}0.76 \\
(0.53)\end{array}$ \\
\hline Mother's father eligible * YOUNG & $\begin{array}{c}-0.70 \\
(0.82)\end{array}$ & $\begin{array}{c}-0.69 \\
(0.65)\end{array}$ \\
\hline Father's father eligible * YOUNG & $\begin{array}{c}0.36 \\
(0.81)\end{array}$ & $\begin{array}{c}0.33 \\
(0.69)\end{array}$ \\
\hline $\begin{array}{l}\text { Control variables: } \\
\text { Family Background variables } \\
\text { Age dummies } \\
\text { Eligibility variables } \\
\text { N. Obs. }\end{array}$ & $\begin{array}{c}\text { Yes } \\
\text { Yes } \\
\text { Yes } \\
1552 \\
\end{array}$ & $\begin{array}{c}\text { Yes } \\
\text { Yes } \\
\text { Yes } \\
1457 \\
\end{array}$ \\
\hline
\end{tabular}

Notes: Standard errors (robust to correlation of residuals within households and heteroscedasticity) in parentheses.

Family background variables: father's age and education, mother's age and education and rural or metro residence family size, number of members aged 0 to 5,6 to 15,15 to 24,24 to 49 , above 50

Age dummies: Dummies for whether the child is born in 1991, 1990, or 1989. Eligibility variables: Mother's mother eligible, Father's mother eligible Mother's father eligible, Father's father eligible (first stages are in table A). 
Table 9: Disposition of income

\begin{tabular}{|c|c|c|}
\hline & \multicolumn{2}{|c|}{ Savings } \\
\hline & OLS & 2 SLS \\
\hline & $(1)$ & $(2)$ \\
\hline Woman's pension & $0.99 *$ & $0.82 *$ \\
\hline income & $(0.093)$ & $(0.16)$ \\
\hline Man's pension & $0.78^{*}$ & $0.53 *$ \\
\hline income & $(0.13)$ & $(0.22)$ \\
\hline Non-pension income & $0.53 *$ & $0.50^{*}$ \\
\hline & $(0.017)$ & $(0.041)$ \\
\hline
\end{tabular}

Notes: Standard errors in parentheses.

Instruments are : dummies for: head is employed, head holds a regular job, a casual wage job, a job an agricultue, sector of the job, employer's type (central or local government, private firm, other), pay type (weekly, fortnightly, monthly), woman eligible and man eligible. 
Table A: First stage regressions: effect of eligibility on pension receipt.

OLS regressions

\begin{tabular}{|c|c|c|c|c|c|c|}
\hline & $\begin{array}{l}\text { Woman } \\
\text { receives } \\
\text { pension }\end{array}$ & $\begin{array}{c}\text { Man } \\
\text { receives } \\
\text { pension }\end{array}$ & $\begin{array}{c}\text { Woman } \\
\text { receives } \\
\text { pension } \\
* \text { YOUNG } \\
\end{array}$ & $\begin{array}{c}\text { Man } \\
\text { receives } \\
\text { pension } \\
\text { *YOUNG }\end{array}$ & $\begin{array}{c}\text { Woman receives } \\
\text { pension } \\
* \text { YOUNG }\end{array}$ & $\begin{array}{c}\text { Man receives } \\
\text { pension } \\
* \text { YOUNG }\end{array}$ \\
\hline & $(1)$ & $(2)$ & (3) & $(4)$ & $(5)$ & $(6)$ \\
\hline \multicolumn{7}{|l|}{ Panel A: Boys } \\
\hline Woman eligible & $\begin{array}{c}0.55^{*} \\
(0.052)\end{array}$ & $\begin{array}{c}0.021 \\
(0.036)\end{array}$ & & & & \\
\hline Man eligible & $\begin{array}{c}0.028 \\
(0.054)\end{array}$ & $\begin{array}{c}0.39 * \\
(0.067)\end{array}$ & & & & \\
\hline Woman eligible $*$ YOUNG & & & $\begin{array}{c}0.70^{*} \\
(0.050)\end{array}$ & $\begin{array}{c}0.025 \\
(0.045)\end{array}$ & & \\
\hline Man eligible $*$ YOUNG & & & $\begin{array}{l}-0.071 \\
(0.059)\end{array}$ & $\begin{array}{c}0.59 * \\
(0.069)\end{array}$ & & \\
\hline Old grandmother * YOUNG & & & & & $\begin{array}{c}0.43^{*} \\
(0.041)\end{array}$ & $\begin{array}{l}-0.015 \\
(0.038)\end{array}$ \\
\hline Old Grandfather * YOUNG & & & & & $\begin{array}{l}-0.049 \\
(0.042)\end{array}$ & $\begin{array}{c}0.27 * \\
(0.043)\end{array}$ \\
\hline N. Obs & 1627 & 1627 & 1627 & 1627 & 1627 & 1627 \\
\hline \multicolumn{7}{|l|}{ Panel B: Girls } \\
\hline Woman eligible & $\begin{array}{c}0.51^{*} \\
(0.057)\end{array}$ & $\begin{array}{l}0.025 \\
(0.03)\end{array}$ & & & & \\
\hline Man eligible & $\begin{array}{c}0.077 \\
(0.052)\end{array}$ & $\begin{array}{c}0.41 * \\
(0.064)\end{array}$ & & & & \\
\hline Man eligible * YOUNG & & & $\begin{array}{c}0.62 * \\
(0.062) \\
0.12 \\
(0.10)\end{array}$ & $\begin{array}{c}0.017 \\
(0.042) \\
0.60 * \\
(0.094)\end{array}$ & & \\
\hline Old grandmother * YOUNG & & & & & $\begin{array}{c}0.40^{*} \\
(0.041)\end{array}$ & $\begin{array}{c}0.021 \\
(0.032)\end{array}$ \\
\hline Old Grandfather * YOUNG & & & & & $\begin{array}{c}0.014 \\
(0.045)\end{array}$ & $\begin{array}{c}0.22 * \\
(0.044)\end{array}$ \\
\hline $\begin{array}{l}\text { N. Obs. } \\
\text { Control variables: }\end{array}$ & 1533 & 1533 & 1533 & 1533 & 1533 & 1533 \\
\hline Presence of older members & Yes & Yes & No & No & No & No \\
\hline Family Background variable & Yes & Yes & Yes & Yes & Yes & Yes \\
\hline Age dummies & Yes & Yes & Yes & Yes & Yes & Yes \\
\hline
\end{tabular}

Notes: Standard errors (robust to correlation of residuals within households and heteroscedasticity) in parentheses.

Family background variables: father's age and education, mother's age and education and rural or metro residence.

Member age variables: family size, number of members aged 0 to 5,6 to 15,15 to 24,24 to 49 , above 50 (columns 3 to 6 ). Age dummies: Dummies for whether the child is born in 1991, 1990, or 1989.

Presence of older members: Dummies for whether there is a woman above 50, a man above 50, a woman above 55, a man above 55, a man above 60 . 
Table A2: Robustness checks--excluding children born in 1991 or including them in the treatment group

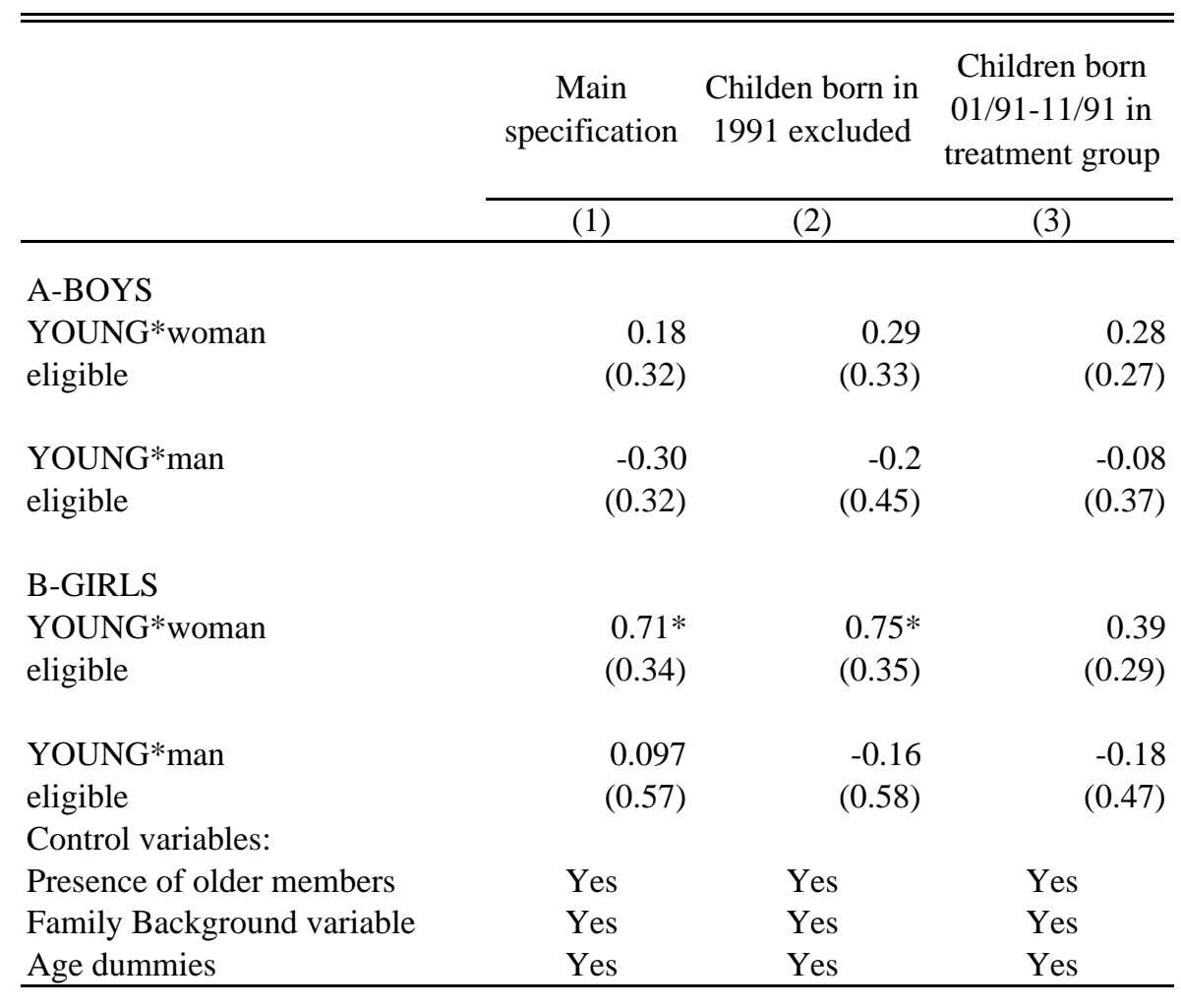

Notes: Standard errors (robust to correlation of residuals within households and heteroscedasticity) in parentheses.

Family background variables: father's age and education, mother's age and education and rural or metro residence, family size, number of members aged 0 to 5,6 to 15,15 to 24,24 to 49 , above 50 Age dummies: Dummies for whether the child is born in 1991, 1990, or 1989.

The instruments in column (1) and (3) are the interactions woman eligible*YOUNG and man eligible*YOUNG.

The instruments in column (2) and (4) are the interactions old grandmother*YOUNG and old grandfather*YOUNG 